\title{
Internalisasi Nilai Kesantunan Berbahasa Melalui Pembelajaran PAI Dan Budi Pekerti
}

\author{
Aiman Faiz', Kama Abdul Hakam², Sofyan Sauri' ${ }^{3}$, Yadi Ruyadi ${ }^{4}$ \\ 1 aimanfaiz@umc.ac.id \\ ${ }^{1}$ Universitas Muhammadiyah Cirebon, ${ }^{2,3,4}$ Universitas Pendidikan Indonesia
}

Submitted

May2, 2020

\section{Revised}

June 23, 2020

https://dx.doi.org/ 10.17509/jpis.v29i1.24382
Accepted

June 25,2020

\begin{abstract}
The politeness used by adolescents today no longer shows the characteristics of a nation that has ethics, norms and morals as a representation of cultural change. This study aims to describe, analyze, plan, process and plan politeness through Islamic religion and character education subjects at SMPN2 Sumber. To retrieve data this study uses a naturalistic paradigm by discussing qualitatively. The results of the study found the importance of planning and the process of internalizing the value of politeness invited to be delivered optimally requested by the teacher about planning and choosing accordingly when the process of internalizing the politeness value was attempted. Strategies developed based on Gardner's theory and general education perspectives can be obtained from the teacher's results must have an ethical and aesthetic basis in communicating with students so that essential values can be conveyed. Thus, internalization of politeness values is expected to be one of the keys to improve grammar among students to be better.
\end{abstract}

Keywords: Manner language, PAl and virtuous teacher, General Education.

\begin{abstract}
ABSTRAK
Kesantunan berbahasa saat ini tidak lagi menunjukkan adanya etika, norma dan moral sebagai ciri sebuah bangsa akibat adanya pergeseran budaya. Penelitian ini bertujuan untuk mendeskripsikan, dan menganalisis perencanaan, proses, hambatan dan strategi kesantunan berbahasa melalui guru mata pelajaran pendidikan agama islam dan budi pekerti di SMPN2 Sumber. Untuk menggali data pada penelitian ini menggunakan pendekatan kualitatif. Hasil penelitian menemukan pentingnya perencanaan dan proses internalisasi nilai kesantunan berbahasa akan tersampaikan dengan optimal apabila seorang guru memahami pentingnya perencanaan dan memilih pendekatan yang sesuai saat proses internalisasi nilai kesantunan berbahasa. Strategi yang dikembangkan berdasarkan pada teori Gardner dan perspektif pendidikan umum dapat diperoleh hasil bahwa seorang guru harus memiliki dasar ethics dan estethic dalam berkomunikasi dengan siswa agar nilai esensial kehidupan dapat tersampaikan. Dengan demikian, dalam internalisasi nilai kesantunan berbahasa diharapkan menjadi salah satu kunci untuk memperbaiki tata bahasa yang ada dikalangan pelajar menjadi lebih baik.
\end{abstract}

Keywords: Santun Berbahasa, guru PAI dan Budi pekerti, Pendidikan Umum.

\section{PENDAHULUAN}

Bahasa menjadi media baik dalam berinteraksi dengan orang lain maupun dalam mengungkapkan perasaan dan gagasannya. Meskipun demikian, bahasa memiliki kesantunan yang berbeda-beda, hal tersebut dipengaruhi pada dimana seseorang itu 
tinggal. Nilai kesantunan saat ini menjadi hal yang sangat dibutuhkan dalam membangun hubungan antar manusia agar dapat saling menghormati. Sebagai alat komunikasi, bahasa mempunyai fungsi dalam menghubungkan antar pikiran manusia. Penggunaan bahasa santun sebagai alat komunikasi perlu juga diperhatikan antara penutur dan mitra penutur untuk menentukan tingkat kesantunan seseorang, misal jarak usia, jarak sosial, situasi dan waktu, tempat dan tujuan tuturan. Artinya, konteks pemakaian bahasa perlu di perhatikan [1].

Sejalan dengan pemikiran Nurjamily, Nur dan Rokhman [2] mengungkapkan bahwa melalui bahasa manusia saling menyampaikan informasi yang berupa pikiran, gagasan, maksud, perasaan bahkan emosinya. Penggunaan bahasa berkait dengan ilmu sosiolinguistik dan pragmatik. Kedua ilmu ini saling berkaitan satu dengan lainnya, bahkan saling melengkapi. Penggunaan bahasa dalam perspektif sosiolinguistik dipengaruhi oleh faktor kebahasaan dan faktor non kebahasaan, contohnya hubungan antar penutur dan mitra tutur, dipengaruhi oleh faktor sosial, budaya dan situasi yang mempengaruhi tingkat kesantunan berbahasa seseorang. Dengan demikian, kesantunan dalam bahasa mengandung relativisme karena akan tergantung pada budaya dan kebiasaan, letak geografis dimana seseorang tersebut tinggal dan dibesarkan.

Menurut [2] yang menjelaskan makna "kesantunan yang merupakan bagian dari ekspresi positif kepada orang lain sehingga dapat memberikan kesan dan menjauhi hal-hal yang menyinggung orang". Kesantunan berbahasa dapat diekspresikan secara lisan (verbal) atau non-verbal yang merupakan metode yang dapat digunakan dalam mengekspresikan nilai kesantunan berbahasa. Budiwati mengatakan penggunaan bahasa antara petutur dan maupun penutur tidak memiliki kesepahaman maka komunikasi tidak akan lancar dan efektif. Namun bisa mengakibatkan terjadinya ketersinggungan dan pertengkaran dikarenakan ketidakpahaman dalam berbahasa santun [3].

Pentingnya kesantunan dalam berbahasa saat ini perlu mendapatkan perhatian secara khusus, apalagi kondisi dewasa ini masyarakat tengah bergerak ke arah yang semakin maju dan modern. Sehingga melahirkan konsekuensikonsekuensi tertentu yang berkaitan dengan nilai dan moral seperti yang diungkapkan Sauri bahwa komunikasi dan teknologi yang saat ini mengalami kemajuan dan menghadirkan pergeseran budaya Barat yang bebas nilai dengan budaya Timur yang penuh norma. Tentunya hal ini membawa dampak pada tatanan nilai-nilai budaya termasuk tata cara seseorang dalam berkomunikasi dengan kesantunan berbahasanya. Bahasa yang saat ini digunakan oleh para remaja seolah memberi isyarat dari hilangnya tatanan nilai etika dalam berbahasa. Budaya ketimuran yang menjadi kebanggaan mulai terkikis dan bukan tidak mungkin akan hilang dari bangsa Indonesia jika tidak diantisipasi secara dini [4].

Dengan kondisi yang telah di jelaskan di atas, tentunya saat ini pendidikan dalam hal ini sekolah dituntut untuk memiliki kemampuan mendidik dan mengembangkan etika berbahasa santun agar siswa dapat berkomunikasi dengan lebih baik. Lingkup pendidikan berperan besar dalam menanamkan nilai kesantunan berbahasa. 
Perlunya pembinaan kondisi siswa saat ini dikarenakan para siswa adalah generasi penerus yang akan hidup pada zamannya. Apabila dibuarkan dengan bahasa mereka, bukan tidak mungkin akan lahir generasi yang arogan, kasar dan tak tersentuh nilai-nilai etika dan agama. Berdasarkan pengamatan menunjukkan hasil percakapan dengan menggunakan bahasa yang kasar dan arogan di kalangan remaja. Hal ini menyebabkan perselisihan dan perkelahian antar mereka [5] Fenomena lain dari permasalahan kebangsaan kita adalah teramcamnya kebhinnekaan dan NKRI yang kian memanas dan tak kunjung selesai. Adanya media sosial tidak dibarengi dengan pengetahuan literasi media yang baik, sehingga banyak generasi bangsa salah dalam menggunakan media sosial. oleh karenanya, menjadi penting kiranya telaah kesantunan berbahasa untuk diteliti [6].

$$
\text { Dalam dunia pendidikan dan bagi }
$$
seorang guru, penggunaan bahasa merupakan bentuk nyata dari komunikasi langsung. Faktor yang menentukan tingkat keberhasilan penggunaan bahasa santun adalah guru sebagai penunjang keberhasilan. Wujud penggunaan bahasa tersebut terlihat seccara nyata dengan adanya penggunaan lisan yang baik, karena bahasa lisan lebih mudah digunakan dan praktis. Penggunaan bahasa lisan harus didukung pula dengan adanya gestur seperti mimik, gerak tubuh dan intonasi yang bertujuan untuk memperjelas maksud yang disampaikan dalam berinteraksi dikelas. Bahasa yang digunakan dalam proses belajar mengajar merupakan komunikasi timbal balik atau komunikasi dua arah antara guru dan siswa atau siswa dengan siswa[7].
Dalam penelitian ini, subjek peran pendidik yang diteliti adalah guru PAI dan Budi Pekerti di SMPN 2 Sumber, hal ini ditujukan karena guru PAI dan Budi pekerti memegang peran yang penting dalam menginternalisasikan kesantunan berbahasa di sekolah. Memang semua guru harus bisa menginternalisasikan nilai kesantunan berbahasasa dalam setiap komunikasinya dengan para siswa, namun guru PAI dan Budi pekerti memegang peran penting, disamping materi yang disampaikan berkaitan dengan dunia akhirat, gurunya pun harus jadi teladan bagi siswa dalam segala hal termasuk bahasa yang santun. Jika meminjam istilah Sauri bahwa pendidikan budi pekerti kaitannya dengan pendidikan jiwa. Dalam perspektif islam budi pekerti atau akhlak merupakan moralitas yang sangat penting. Dengan demikian, kajian dalam pendidikan budi pekerti harus berkaitan dengan implementasi dan praksis dalam perilaku sehari-hari di lingkup keluarga, sekolah maupun masyarakat [5].

Disisi lain, jika ditinjau keberadaannya dalam kurikulum nasional, PAl dan budi pekerti yang merupakan salah satu mata pelajaran yang selalu ada di dalam kurikulum pendidikan formal di Indonesia khususnya. Alasannya sangat logis karena PAl yang esensi didalamnya mengajarkan bagaimana cara untuk hidup beragama merupakan salah satu dimensi yang harus dimiliki oleh setiap warga negara. Oleh sebab itu, peran pendidikan Agama (PAI) mengemban tugas berat sehingga perlu adanya formulasi yang dapat didukung oleh sumber daya manusia yang baik yang memiliki metode, kualitas yang menunjang bagi kemajuan pendidikan agama khusunya [8]. Pentingnya 
menyadarkan peserta didik dalam membangun kesantunan berbahasa melalui pendidikan formal sangatlah penting. Sebagai lembaga resmi yang memiliki fungsi melaksanakan pembelajaran, wajib rasanya kesantunan bahasa ini di internalisasikan karena bahasa memegang peran penting dalam proses pendidikan [9].

Berdasarkan deskripsi yang telah diungkapkan di atas, betapa pentingnya seorang guru terutama guru PAI dan Budi pekerti dalam menginternalisasikan nilai kesantunan berbahasa. Faktor yang menyebabkan timbulnya bahasa yang tidak santun salah satu diantaranya disebabkan oleh minimnya perhatian berbahasa santun secara khusus dari praktisi pendidikan. Oleh karena itu, maka penelitian ini dirasa penting karena melihat kondisi yang ada berkaitan dengan nilai kesantunan berbahasa dikalangan remaja ini mengalami penurunan. Jika tidak mendapatkan perhatian, maka bukan tidak mungkin hal ini akan mendorong terjadinya arogan dari para pelajar. Untuk itu, berdasarkan fakta sebelumnya maka peneliti membuat penelitian dengan judul "Internalisasi nilai kesantunan berbahasa melalui pembelajaran PAI dan Budi pekerti di SMPN 2 Sumber". Dengan adanya penelitian ini, besar harapan akan memberikan solusi alternatif pendidikan yang dapat menanamkan nilai-nilai kesantunan berbahasa saat ini yang semakin urgent dan penting.

\section{KAJIAN LITERATUR}

Peran guru dalam internalisasi nilai kesantunan berbahasa

Dalam bukunya tentang berbahasa santun Sauri mengungkapkan bahwa pembinaan yang kesantunan berbahasa kurang mendapatkan perhatian maksimal dari berbagai lapisan masyarakat [5]. Dari uraian di atas, dapat dikemukakan beberapa fakta yang terjadi di masyarakat perlu ditinjau dan ditegaskan kembali tentang bagaimana bahasa santun dapat diterima dimasyarakat, yaitu:

1. Pertama, banyak orang menggunakan lidahnya secara bebas tanpa didasari oleh pertimbangan-pertimbangan moral, nilai, dan agama.

2. Kedua, penggunaan bahasa yang tidak santun akan melahirkan ketersinggungan dalam berkomunikasi dalam tatanan masyarakat

3. Ketiga, remaja saat ini berkomunikasi tidak menggunakan bahasa yang santun

4. Keempat, perilaku yang santun senantiasa terlihat dari sikap siswa saat bertegur sapa dengan guru, karyawan dan sesama siswa. Perilaku tidak santun akan muncul saat ada teguran, perintah atau larangan yang tidak sesuai dengan hati nurani siswa.

Guru sebagai teladan bagi siswa hendaknya dapat menjadi model kesantunan berbahasa, karena siswa pada dasarnya seperti spons yang menyerap apa saja yang di serap dari sekitarnya. Artinya, guru harus menanamkan nilai santun berbahasa kepada peserta didik menggunakan strategi keteladanan atau modeling yang langsung dilihat oleh siswa. Seperti yang diungkapkan oleh Lickona mengungkapkan seorang guru harus menjadi model dalam ber-etika di kelas sehingga dapat membangun komunikasi yang positif dengan siswa 
dengan berlandaskan pada etika kesantunan berbahasa. Kesadaran pentingnya seorang guru memiliki visi moral bertujuan agar terjadi koneksi antara guru dan siswa berlandaskan etika dan moral dalam kesantunan berbahasa [10].

Pada kenyataannya, di sekolah masih guru-guru yang bertindak secara otoriter kepada siswa, sebagian mereka mengaggap tindakan yang berbau kekerasan baik verbal maupun nonverbal sebagai upaya mendisiplinkan siswa dan masih dianggap ampuh di terapkan di sekolah. Hal tersebut menjadikan pendidikan seolah-olah tidak humanis dan tidak demokratis bagi siswa [11]. Bahkan Doni Koesoema, penulis buku Pendidikan Karakter menyindir secara halus dan mengatakan "ciri khas guru Indonesia itu galak, jika tidak galak bukan guru Indonesia". Dengan ungkapan tersebut, maka perlu adanya penanaman kembali terkait nilainilai kesantunan berbahasa antara guru dengan siswa sebagai upaya pembentukan karakter siswa yang santun. Hal ini bertujuan agar terciptanya kembali iklim moral yang sehat didalam kelas maupun lingkungan sekolah. Karena udara moral yang baik akan menghasilkan paru-paru yang sehat juga [12]. Artinya, jika guru memberikan keteladanan yang baik maka akan melahirkan siswa-siswa yang memiliki kesantunan dalam berbahasa yang dapat berpengaruh pada karakter siswa.

Penggunaan kesantunan berbahasa menjadi salah satu indikator generasi yang berkarakter. Mentradisikan dan menginternalisasikan kesantunan berbahasa merupakan upaya dalam menyiapkan generasi bangsa yang berkarakter dan dibutuhkan dalam menghadapi era globalisasi ini. Peran pendidik dan orang tua tentunya dapat menjadi model dalam menanamkan nilai kesantunan berbahasa [13].

\section{Kajian Penelitian Yang Relevan}

Penelitian tentang "Guru sebagai Model Kesantunan Berbahasa dalam Interaksi Instruksional di Sekolah Dasar". Dalam pembelajaran di SD (Sekolah Dasar), guru merupakan figur yang diteladani oleh siswa. Karena itu, dalam menanamkan karakter santun dalam berbahasa, guru harus mampu menjadi model kesantunan berbahasa bagi anak didiknya. Teori kesantunan yang dapat diaplikasikan oleh guru dalam pembelajaran adalah teori kesantunan [13] khususnya penggunaan strategi kesantunan positif. Dengan penerapan strategi kesantunan positif, guru dapat membangun kedekatan hubungan dengan siswa. Dengan adanya kedekatan hubungan ini diharapkan interaksi interaksional guru dengan siswa dapat berjalan dengan harmonis. Dengan demikian, tujuan pembelajaran akan dapat dicapai dengan baik.

Selanjutnya, penelitian Membangun Karakter Peserta Didik Melalui Kesantunan Berbahasa. Dapat diambil simpulan bahwa kesantunan berbahasa peserta didik di madrasah ibtidaiyah Alhidayatus salafiyah perlu mendapat perhatian lebih. Tata cara berbahasa peserta didik dipengaruhi oleh unsur-unsur budaya dan kebiasaan yang ada dalam masyarakat. Peserta didik seringkali bergaul dengan orang yang lebih tua, sehingga memengaruhi cara anak berbahasa. Madrasah Ibtidaiyah sebagai salah satu lembaga pendidikan yang berbasis agama harus menjadi wadah bagi penanaman kebiasaan baik, salah satunya kesantunan berbahasa. Selain itu, Tim pelaksana menyarankan penerapan kesantunan berbahasa dapat dilakukan 
dengan cara membiasakan diri berbahasa santun, baik di sekolah maupun di rumah.

Kemudian,

penelitian

membangun bangsa berkarakter santun melalui pendidikan nilai di persekolahan. Berdasarkan kajian berbahasa di kalangan siswa ditemukan bahwa pada umumnya mereka menggunakan kosa kata bahasa yang kurang santun dilihat dari segi pragmatik. Kosa kata yang digunakan sebagian besar merupakan bahasa gaul dan bahasa preman. Bahasa gaul secara pragmatik terdapat yang wajar digunakan dan tidak wajar, dan sebagian besar dipandang tidak santun.

Bahasa gaul yang dipandang oleh siswa wajar merupakan ucapan dalam komunikasi antar mereka di sekolah, dan dipandang tidak sopan, ketika dikatakan kepada guru. Standar yang diterapkan dalam berbahasa yaitu budaya masyarakat Indonesia terutama budaya Sunda. Sementara itu berbahasa santun, lebih banyak dipengaruhi oleh nilai-nilai agama. Pengaruh agama lebih banyak terlihat pada pemilihan kosa kata dalam pergaulan kegiatan keagamaan. Yang membedakan antara ketiga penelitian terdahulu dengan penelitian ini adalah bagaimana seorang guru sadar akan perencanaan, proses, hambatan dan bagaimana strategi yang dikembangkan dalam menginternalisasikan nilai kesantunan berbahasa. Selain itu, subjek mata pelajaran PAI dan Budi pekerti juga menjadi ciri khas pada penelitian ini. Pentingnya internalisasi nilai kesantunan berbahasa melalui seorang guru merupakan kunci dalam tercapainya proses pembelajaran yang santun dan bernilai

\section{METODE PENELITIAN}

Pada penelitian ini menggunakan paradigma naturalistik dengan pendekatan kualitatif, sedangkan metode yang digunakan sesuai dengan karakter penelitiannya sebagaimana diungkapkan oleh Denzin dan Lincoln (dalam Moleong) yang menyatakan bahwa penelitian kualitatif adalah penelitian dengan menggunakan latar alamiah. Hal ini dimaksudkan untuk menafsirkan fenomena yang terjadi dengan melibatkan berbagai metode yang ada. Sehingga menghasilkan data deskriptif yang menurut Bogdan dan Taylor (dalam Moleong) bahwa metode kualitatif yang menghasilkan data deskriptif berupa-kata-kata tertulis atau lisan dari orang yang dapat diamati dan berkaitan dengan internalisasi nilai kesantunan berbahasa dalam pembelajaran PAI dan Budi Pekerti [14]. Instrumen penelitian adalah peneliti itu sendiri, sebagai human instrument terjun langsung ke lapangan untuk mengumpulkan data. Data-data yang diperoleh dari lapangan melalui observasi atau pengamatan, wawancara dan studi dokumen yang ada kaitannya dengan topik tesis. Penelitian ini menekankan bahwa peneliti berinteraksi langsung dengan subjek dan responden. Adapun responden yang terlibat adalah guru pengejar PAI dan Budi pekerti berjumlah 4 orang. Alasan mengambil subjek guru PAI dan Budi pelerti karena guru PAI dan Budi pekerti memegang peran yang penting dalam menginternalisasikan kesantunan berbahasa di sekolah. Memang semua guru harus bisa menginternalisasikan nilai kesantunan berbahasasa dalam setiap komunikasinya dengan para siswa, namun guru PAI dan Budi pekerti lah yang dirasa paling utama.

\section{HASIL DAN PEMBAHASAN}

Mengembangkan keterampilan berbicara dengan santun merupakan konsep pembelajaran yang memberikan 
makna dari setiap bahasa yang dipelajari. Dengan memadukan konsep bahasa dengan keterampilan berbahasa yang santun melalui pendidik merupakan salah satu tujuan untuk membentuk karakter dan budi pekerti sebagai upaya melestarikan identitas bangsa Indonesia yang ramah dan santun [15]. Tentunya, peran seorang pendidik dalam memberikan pengaruh karakter kepada siswa sangatlah penting, diantaranya; 1) pendidik harus melibatkan diri dalam proses pembelajaran dengan melakukan interaksi dalam memberikan materi pembelajaran, 2) pendidik harus menjadi model bagi peserta didik dalam berperilaku dan berucap, 3) memberikan kesempatan pada peserta didik agar siswa termotivasi, 4) mampu memberikan perubahan kepribadian agar tercipta hubungan saling menghormati dengan peserta didik, 5) mengembangkan aspek sosio emosinya, 6) menunjukkan kepedulian kepada peserta didik dengan menggunakan bahasa yang penuh cinta dan kasih saying [13].

Bahasa sebagai alat dalam berkomunikasi dan berinteraksi antar individu maupun kelompok. Dalam bukunya Geertz memberikan penjelasan terkait kesantunan berbahasa yang digunakan masyarakat harus memperhatikan hubungan sosial antar pembicara dengan penyimak. Bagi Geertz, nilai kesantunan berbahasa merupakan hal yang harus diperhatikan sehingga efek yang ditimbulkan akan berimbas pada adanya keakraban antara penutur dengan yang merespon atau pendengar. Bahkan secara lebih jauh bahasa santun merupakan ciri dari status sosial masyarakat penggunanya [16]. Jika ditinjau dari sudut pandang moral, Suryalaga memberikan pendapatnya tentang bahasa santun harus digunakan untuk saling menghormati antar manusia. Berbahasa dengan santun artinya berkaitan dengan penggunaan bahasa dalam keseharian, atau dalam pergaulan antar teman sebaya, orang tua maupun masyarakat. [17] Peran guru dalam menginternalisasikan nilai kesantunan berbahasa, merupakan syarat pribadi yang dilandasi pada ketentunan yang berkaitan dengan nilai diri dan tingkah laku yang diperlolehnya sebagai kemampuan intelektua, sikap dan emosiomal [5]. Dengan demikian, tugas seorang guru dalam lingkup sekolah menjadi komponen penting dalam membangun kembali kebiasaan siswa berdasarkan pertimbangan moral yang baik. Seorang guru yang baik akan senantiasa bersikap dan berucap secara santun, karena guru adalah penentu didalam kelas sebagaimana yang diungkapkan oleh Arikunto bahwa guru merupakan orang yang paling memiliki kedudukan penting dalam proses belajar mengajar di kelas, alasannya karena guru memegang penting yaitu mengatur dan mengarahkan kelas. Guru sebagai aktor dikelas diharapkan dapat membiasakan dan menyampaikan substansi ilmunya dengan kesantunan berbahasa [18].

\section{Perencanaan Dalam Internalisasi Nilai Kesantunan Berbahasa Melalui Guru Pai Dan Budi Pekerti}

Dalam perencanaan terkait pendidikan karakter harus dilakukan secara terencana, agar niat, kehendak dan kemauan untuk mengembangkan pendidikan karakter di sekolah dapat tercapai. Tanpa adanya niat yang direncanakan, pendidikan karakter bersifat marjinal dalam kinerja sebuah sekolah. Sekolah akan dengan mudah mengabaikan pendidikan karakter. Sementara itu, para guru dengan 
kewajiban mereka mengajar mata pelajaran yang diampu. Secara proaktif dan intensif, sekolah mengarahkan pembentukkan karakter terhadap siswa dalam setiap kelas, serta anggota komunitas lain terlibat dalam desain dan perencanaan strategis pendidikan karakter. Tanpa adanya perencanaan secara sadar, keberhasilan pendidikan karakter tidak dapat dievaluasi dan dinilai. Jika kita tidak dapat menilai dan mengevaluasi pendidikan karakter, kita pun juga tidak akan memiliki informasi untuk mengembangkannya lebih lanjut [19]. Seorang guru yang baik dan profesional senantiasa membuat persiapan terlebih dahulu karena guru adalah merupakan penentu dalam kegiatan di kelas, guru menjadi peran penting dalam mengatur dan mengendalikan kelas. Oleh sebab itu substabsi kegiatan belajar dapat tersampaikan karena perencanaan yang telah di susun oleh guru.

Berdasarkan hasil temuan dilapangan dengan beberapa informan dan melakukan cross cek ke beberapa narasumber terkait perencanaan internalisasi nilai kesantunan berbahasa melalui peran guru PAI dan Budi pekerti. Hasil temuan terlihat bahwa internalisasi nilai kesantunan berbahasa sudah terlaksana dengan baik. Sebagai media pendidikan karakter kegiatan pembelajaran dengan kesantunan berbahasa memang perlu dilaksanakan dengan perencanaan yang terstruktur dan sistematis. Guru sebagai komponen penting dalam kegiatan belajar mengajar yang menentukan jalannya kegiatan harus selalu memiliki rencana dan tujuan agar kegiatan belajar mengajar berjalan sesuai dengan sasaran yang ingin dicapai salah satunya menggunakan komunikasi edukatif yang berbasis kesantunan berbahasa. \begin{tabular}{ll}
\multicolumn{2}{c}{ Perencanaan tersebut bisa } \\
terlihat dalam RPP, didalam RPP
\end{tabular} disebutkan dalam Kompetensi inti nomor 2 bahwa seorang guru harus menghargai dan menghayati perilaku jujur, disiplin, bertanggung jawab, peduli (toleransi, gotong royong), santun, percaya diri dalam berinteraksi secara efektif dengan lingkungan sosial dan alam dalam jangkauan pergaulan dan keberadaannya. Jika diligat santun menjadi cara atau metode dalam menyampaikan mata pelajaran dengan edukatif berbasis kesantunan berbahasa. Apabila seorang guru tidak memenuhi kriteria $\mathrm{KI}-2$ tadi, tentunya perlu diperbaiki lagi cara mengajarnya agar pembelajaran di dalam kelas dapat menginternalisasikan materi yang disampaikan dengan bahasa santun. Rumusan perencanaan tersebut juga untuk mempermudah guru dalam menginternalisasikan nilai yang difokuskan dan menghindari kegiatan belajar mengajar yang tidak berisikan nilai-nilai edukatif berbasis bahasa santun.

Dengan demikian, setiap kegiatan yang berkaitan dengan mendidik harus selalu berkaitan dengan perencanaan, tujuannya untuk mengukur hasil rumusan perencanaan agar kegiatan tersebut lebih jelas arah dan tujuannya. Hal tersebut sejalan dengan yang diungkapkan oleh Kaufman (dalam Irwantoro dan Suryana) yang mengungkapkan bahwa perencanaan adalah suatu proses untuk menentukan "kemana harus pergi" dan bagaimana untuk mencapai ke tempat yang kita tuju dengan cara yang paling efisien dan efektif. Pentingnya perencanaan dimaksudkan agar guru lebih siap dalam melaksanakan proses kegiatan belajar mengajar dengan penuh nilai edukatif kesantunan berbahasa sebagai penguat pondasi 
kesantunan berbahasa ditengah zaman yang semakin mengkhawatirkan [20].

\section{Proses Internalisasi Nilai Kesantunan Berbahasa Melalui Guru Pai Dan Budi Pekerti}

Saat proses pembelajaran, pendidik memiliki peran yang vital, salah satunya mampu menciptakan kondisi belajar yang kondusif sehingga peserta didik mampu melakukan proses pembelajaran dengan suasana yang kondusif. Suasana yang kondusif dapat diperoleh melalui guru yang ramah dan santun [21]. Berdasarkan hasil temuan dilapangan, proses internalisasi nilai kesantunan berbahasa melalui guru PAI dan Budi pekerti di sekolah berjalan dengan baik. Hal tersebut dapat terlihat bahwa guru melakukan komunikasi edukatif dengan penuh kesantunan saat menyampaikan materi pelajaran. Berdasarkan pengamatan, terlihat peran guru dalam proses pembelajaran menunjukkan dirinya sebagai seorang fasilitator, motivator, dan evaluator berlandaskan kesantunan berbahasa.

Interaksi

dimana

berlangsungnya kegiatan pembelajaran terlihat sangat efektif karena guru berhasil mengkondisikan kelas dengan baik. Guru menjadi satu komponen penting dalam proses penanaman nilai kesantunan berbahasa di kelas. Sebagaimana yang diungkapkan Arikunto, bahwa guru dipercaya untuk mengolah siswa dengan mentransfer berbagai aspek baik itu pengetahuan, keterampilan maupun sikap yang dipersiapkan untuk menghadapi masa yang akan dating [18]. Pengolahan tersebut bisa berupa intervensi sebagai penguatan karakter dan stimulus sebagai upaya penanaman nilai kesantunan berbahasa melalui guru PAI dan Budi pekerti.
Proses internalisasi nilai kesantunan berbahasa adalah proses penanaman nilai dari luar kedalam diri (siswa) melalui peran guru. Pendapat tersebut sejalan dengan pendapat Hakam yang mengungkapkan proses internalisasi hakikatnya sebagi upaya menghadirkan nilai yang berasal dari luar (dunia eksternal) menjadi milik seseorang (internal). Dasar dari internalisasi merupakan sebuah proses penanaman suatu nilai yang harus dihayati oleh peserta didik yang berkaitan dengan pemahaman, perasaan, keyakinan, kepribadian atau karakter tentang nilai kesantunan berbahasa yang diwujudkan dalam sikap siswa saat berkomunikasi dengan gurunya [22].

Ke efektifan proses pelaksanaan internalisasi nilai kesantunan berbahasa di SMPN 2 Sumber karena adanya paksaan yang mengharuskan siswa memilih bahasa yang baik saat berkomunikasi dengan guru dikelas, kemudian dari keterpaksaan itu akan menjadi kebiasaan dan kebiasaan tersebut akan menjadi kebutuhan bagi para siswa. Keterpaksaan ini bisa dikategorikan kedalam teori kontrak sosial Tomas Hobbes yang mengatakan bahwa manusia menciptakan dan mematuhi aturan dalam rangka perlindungan diri, minat dan kelayakannya. Dengan demikian, keterpakaan akan membawa siswa menuju perubahan yang di inginkan. Syah mengatakan proses pembelajaran menghendaki sebuah perubahanperubahan dalam kebiasaannya perubahan ini bisa terjadi dengan cara mengulang-ngulang kegiatan dalam kehidupannya, karena kebiasaan menurut Schunk adalah kecenderungan yang dipelajari dan diaplikasikan dalam perilaku-perilaku. 
Selain itu, peran guru sebagai subjek penting berjalannya sebuah kegiatan dalam menanamkan nilai-nilai sebagaimana dinyatakan oleh Nucci bahwa guru adalah subjek penting dalam menanamkan nilai-nilai kepada anak, metodenya ialah melalui keteladanan, keterikatan emosi dengan kelompok, dan penggunaan yang tepat dari penghargaan dan hukuman. Sejalan dengan Nucci, Hurlock mengatakan bahwa: Identification is often called "learning by imitation". More correctly defined, identification is the process by which a person takes over the values of another by imitation. It is the "tendency to view oneself as one with another person and to act accordingly". In identification, the individual tries to duplicate in his own life the ideas, attitudes, and behavior of the person he is imitating.

Pernyataan Hurlock tersebut memberi ketegasan bahwa adanya pembiasaan, keteladanan, dan pengkondisian suasana moral di kelas maupun di lingkungan sekolah menjadi salah satu teknik pendekatan saat proses penanaman nilai dalam hal ini yang berkaitan daengan kesantunan berbahasa yang diterapkan oleh guru pembelajaran PAI dan Budi pekerti. Dengan demikian, guru sebagai aktor utama dalam proses internalisasi nilai kesantunan berbahasa melalui peran guru pembelajaran PAI dan Budi pekerti harus bisa memberikan stimulus kepada siswa mengenai makna simbolik melalui bahasa santun. Tanpa adanya stimulus atau rangsangan siswa belum bisa memahami apa makna dari bahasa yang digunakan oleh guru tersebut. Dari stimulus yang dilakukan oleh guru-pun kita dapat melihat tingkat kesantunan berbahasa siswa saat berkomunikasi dengan guru.

\section{Hambatan Dalam Internalisasi Nilai Kesantunan Berbahasa Disekolah}

Berdasarkan hasil pengamatan disertai wawancara dengan beberapa siswa, disimpulkan bahwa faktor yang menjadi penghambat dalam berbicara sesuai dengan kesantunan yang baik diantaranya adalah lingkungan sosial teman sebaya, adanya role model yang mereka lihat baik di dunia nyata maupun di dunia maya dan kurangnya intervensi dan waktu efektif dalam melakukan komunikasi antara orang tua dan siswa. Tentu hal ini menjadi tantangan tersendiri khususnya bagi guru dan praktisi di bidang pedidikan yang harus bisa menjawab tantangan tersebut, mengingat kondisi saat ini yang turut diperburuk dengan adanya kemajuan teknologi yang menjadi ancaman dan hambatan yang nyata bagi siswa.

Kondisi kemajuan teknologi ini justru dimanfaatkan oleh para orang tua yang sibuk, sehingga para orang tua lebih memilih memberikan gadget pada anaknya dan merelakan waktu bersama dengan anaknya. Hasilnya, banyak orang tua yang kurang dalam berkomunikasi akibat adanya gadget yang menyibukkan antara anak dan orang tua itu sendiri. Selain kurangnya intervensi dari orang tua, adanya contoh model atau role model yang saat ini di jadikan acuan nilai yang mengalahkan guru dan orang tuanya. Salah satu, diantaranya, publik figur seperti selebritis atau artis yang mempengaruhi karakter anak, adannya film-film yang mereka gemari yang didalamnya menggunakan bahasa yang tidak santun sangat berpengaruh bagi kualitas nilai dan karakter peserta didik. Para artis yang menjadi konsumsi tontonan oleh siswa turut memberikan nilai-nilai yang bertolak belakang dengan nilai luhur agama dan moralitas bangsa yang diterapkan disekolah. 
Hal ini tentu memberikan konflik nilai dan nilai menjadi bias. Anak yang belum mengerti akan menganggap penggunaan bahasa yang diucapkan oleh orang lain (selebritis) yang mereka lihat adalah hal yang wajar untuk digunakan dalam bahasa sehari-hari.

$$
\text { Peran media dalam }
$$

berkomunikasi terkadang menggunakan prinsip "bad issues good news". Sementara di sisi lain banyak anak-anak menonton, menyimak dan mencerna semua yang datang lewat media salah satunya media sosial. Sehingga media sedikit sekali membawa edukasi dan minim nilai-nilai di dalamnya bagi para siswa. Hal ini di perkuat oleh pernyataan Cohen dan Tester yang dengan tegas menyatakan media menjadi agen kebejatan moral, ungkapan tersebut ada benarnya karena memang jika diperhatikan saat ini media sedikit sekali memberikan edukasi bagi siswa dan masyarakat pada umumnya. Media saat ini lebih mementingkan rating/ viral daripada edukasi bagi para penerus bangsa. Tentunya kondisi ini membawa ke khawatiran bagi guru karena semakin sulitnya nilai-nilai pendidikan karakter di tanamkan dalam diri siswa [12].

Pandangan pakar psikolog Seto Mulyadi mengungkapkan apabila penggunaan dan media sosial maupun TV tidak dikontrol oleh para orang tua tentu akan membawa dampak negatif. Kekhawatiran yang diungkapkan oleh Seto Mulyadi tersebut mulai dirasakan saat ini, banyak anak yang tumbuh menuju usia remaja terjerumus kedalam kenakalan remaja akibat terlalu bebas meniru hal negatif di sosial media. Unsur negatif yang masuk melalui teknologi dari hari kehari akan membuat anak semakin liar, anak menjadi pemberontak, menjadi pelaku kejahatan, berbicara kurang sopan dan lain sebagainya [18].

Dengan demikian, faktor penghambat internalisasi nilai kesantunan bahasa secara global di SMPN 2 Sumber akibat adanya role model negatif yang mereka tiru dari televisi dan media sosial yang mereka lihat, kurangnya kontrol orang tua dalam memberikan pengawasan semakin memperkeruh tatanan nilai dalam diri siswa. Selain itu, kurangnya intervensi dan waktu efektif dalam melakukan komunikasi antara orang tua dan siswa turut menurunkan kualitas nilai kesantunan berbahasa pada diri siswa. Perlu adanya kesadaran dari orang tua dan guru dalam memberikan penguatan nilai kesantunan bahasa pada siswa [23].

\section{Strategi Internalisasi Nilai Kesantunan Berbahasa Yang Perlu Di Kembangkan}

Dalam pendidikan karakter terdapat empat pilar yang bisa dijadikan rujukan dalam pengembangan strategi pendidikan nilai diantaranya:

1. Olah pikir kaitannya dengan penggunaan nalar seseorang agar kritis, kreatif dan innovatif sehingga melahirkan pribadi yang cerdas.

2. Olah hati berkaitan dengan perasaan dan keyakinan sehingga menghasilkan pribadi yang memiliki perasaan.

3. Olah raga berkaitan dengan persepsi, kesiapan, peniruan, manipulasi dan penciptaan aktivitas baru yang berkaitan dengan sportivitas yang menghasilkan prinadi kuat dan tangguh.

4. Olah rasa dan karsa berkaitan dengan adanya kemauan yang tercermin dalam kepedulian. 
Tabel Skema empat karakter utama

\begin{tabular}{|c|c|}
\hline $\begin{array}{c}\text { OLAH PIKIR } \\
\text { Cerdas }\end{array}$ & $\begin{array}{c}\text { OLAH HATI } \\
\text { Jujur }\end{array}$ \\
\hline OLAH RASA & OLAH RAGA \\
Peduli & Tangguh \\
\hline
\end{tabular}

Sumber: Budimansyah

Seorang guru harus mampu mengembangkan empat pilar karakter utama dalam dirinya terlebih dahulu agar dapat menularkannya kepada siswa. Dalam praktiknya penanaman nilai-nilai yang dikembangkan dimulai dari hal-hal yang sederhana seperti menggunakan kalimat yang santun saat berkomunikasi. Jika mengacu pada teori Howard Gardner yang di kaitkan dengan skema empat pilar karakter utama, seseorang yang memiliki kecerdasan linguistik dapat di realisasikan kedalam kesantunan bahasa. Artinya orang yang memiliki kecerdasan linguistik, dia pasti memiliki olah pikir yang baik sehingga apa yang terpikir dan keluar dari lisannya adalah kalimat-kalimat yang baik [24].

Kecerdasan bahasa atau sering disebut linguistic intelegence merupakan bagian dari keterampilan individu dalam menguasai bahasa tulisan dan lisan. Shearer mengungkapkan ciri dari kecerdasan bahasa meliputi penggunaan kata dan kalimat secara efektif dalam membaca, menulis dan berbicara. Keterampilan berbahasa menjadi hal yang penting untuk memberikan berbagai ide dan gagasan. Banyak orang dengan kecerdasan berbahasa yang dimiliki sehingga dapat membuat karya berupa syair atau tulisan dengan karya yang ekspresif [6].

Seorang guru yang cerdas secara linguistik harus menginternalisasikan nilai kesantunan berbahasa kepada siswa dalam pembelajaran. Komunikasi yang diciptakan oleh guru harus mampu menarik perhatian siswa dengan memberikan suasana pembelajaran yang efektif dengan nilai sopan santun didalamnya disertai gesture yang ada didalamnya. Selain kecerdasan linguistic atau verbal, gurupun harus mampu memberikan arahan dan sentuhan secara psikologis dan emosinal (nonverbal) sehingga dapat mendorong siswa untuk mengikuti pembelajaran nilai kesantunan berbahasa [13].

Jika tinjau dalam perspektif Pendidikan Umum atau karakter, seorang guru harus menjadi sosok manusia yang memiliki keutuhan dalam berpikir, bertindak dan memiliki nilainilai kesantunan yang dapat di internalisasikan ke para siswa. Dalam hal ini, bukan bentuk keahlian khusus tentang bahasa, namun kemampuan dan keterampilan berbahasa yang perlu dimiliki oleh seorang guru [25]. Oleh sebab itu, pendidikan umum memiliki tujuan membina manusia agar mampu berpikir dan berkomunikasi berdasarkan kepada nilai-nilai bermuatan moral maupun berlandaskan agama. Jika ditunjau dalam pembagian ilmu, bahasa merupakan bagian dari humaniora yang didalamnya termasuk juga seni dan budaya. Pendidikan umum berkaitan dengan humaniora terutama dengan sumbangannya dalam mewujudkan pribadi yang utuh seperti tujuan dalam pendidikan umum. Salah satu upaya membentuk manusia utuh agar mampu berpikir dan berkomunikasi sesuai dengan nilai-nilai yang baik. McConnel (dalam Sauri) menjelaskan tentang konsep pendidikan umum yang mampu melahirkan manusia yang memiliki kemampuan berpikir dan berkomunikasi, membuat kebijakan secara cerdas dan bijaksana.

Perspektif

Phenix mengungkapkan bahwa pendidikan umum mencakup enam bidang makna yang harus dipelajari oleh seorang guru agar dapat menghasilkan manusia yang mampu memandang nilai-nilai esensial 
kemanusiaan diantaranya: symbolics, empirics, esthetics, synnoetics, ethics, and synoptics. Phenix menyebutnya enam pola dasar mengenai makna. Dalam enak makna esensial, posisi kesantunan dalam berbahasa terdapat pada sistem symbolics meaning yang didalamnya terdapat bahasa sehari-hari yang memiliki nilai didalamnya sehingga guru dapat berbicara dengan penuh makna yang memabawa pembelajaran lebih bermakna. Dengan konsep ini, anak akan dibimbing agar dapat memiliki kemampuan dalam berbahasa yang penuh kesantunan. Artinya, dengan bahasa sebagai simbol-simbol komunikasi menjadikan dapat saling memahami satu sama lainnya. Kesantunan berbahasa dalam berinteraksi tidak datang secara alami, namun harus diperoleh melalui proses pendidikan dan latihan agar terbiasa menggunakan kalimat yang santun dan berkualitas [15].

Selain itu, kesantunan berbahasa dalam perspektip Pendidikan Umum tak hanya berkaitan dengan symbolic meaning, namun seorang guru juga harus memperhatika makna ethics dan estethic yang didalamnya meliputi makna-makna moral. Dengan pola ini anak akan diberi pemahaman dan kemampuan moralitas, sehingga dalam kehidupannya senantiasa mempertimbangkan nilai, etika dan sopan santun saat berkomunikasi dengan orang lain. Kemudian makna estetika akan membawa siswa memiliki keindahan berbahasa, agar menjadi individu yang dapat menyampaikan pesan melalui bahasa dengan baik, benar dan indah kepada orang lain.

Berdasarkan uraian yang telah dijelaskan di atas, maka peneliti membuat strategi yang dibuat dalam peta konsep sederhana yang kaitannya dangan bagaimana seorang guru menjadi teladan bagi siswanya dalam menginternalisasikan nilai kesantunan berbahas. Adapun konsep dan konsep tersebut disusun seperti di Bagan 1.

Strategi yang di peta kan dalam konsep internalisasi nilai kesantunan berbahasa diharapkan dapat memotivasi siswa dan mau berbahasa dengan santun melalui peran pendidik. Karena pada hakikatnya kemampuan dalam berpikir, berbicara dan berkomunikasi merupakan fitrah manusia yang kemudia mengalami proses perkembangan dengan sentuhan dunia pendidikan di dalamnya. Dengan demikian, pengembangan kesantunan berbahasa melalui perspektif pendidikan umum yang dikembangkan melalui guru PAI dan Budi pekerti akan membawa output yang dapat mempengaruhi siswa agar mampu dan memiliki konsep berkomunikasi dengan bahasa yang ideal berdasarkan pada nilai etika dan agama sebagai fondasinya [26].

\section{Bagan. Konsep danstrategiinternalisasi nilai kesantunan berbahasa}

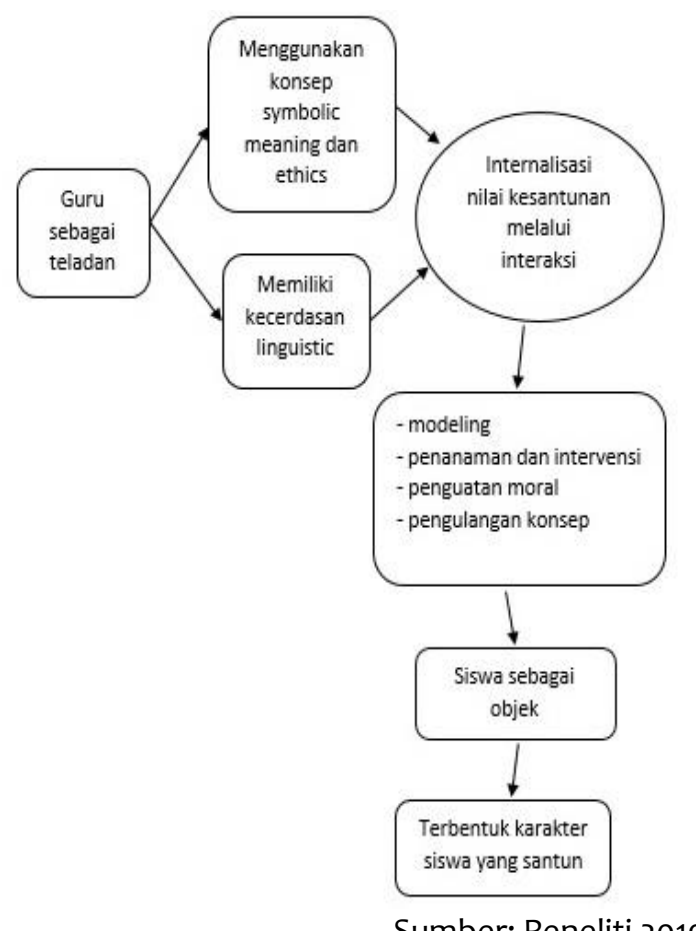

Sumber: Peneliti 2019 
Kesantunan berbahasa yang di internalisasikan melalui konsep-konsep pendidikan umum diharapkan menjadi konsep baru dalam menginternalisasikan nilai kesantunan berbahasa bagi para siswa. Peran guru sebagai model dan keteladanan akan mengarahkan potensi siswa ke arah yang lebih baik, karena pada dasarnya manusia sebagai mahluk moral memiliki potensi dalam dirinya untuk dapat berinteraksi dengan bahasa-bahasa yang santun. Interaksi sosial antar guru dan murid akan dapat menjadi satu kesepakatan norma acuan yang menjadi pegangan bersama dan di implementasikan di lingkungan pendidikan.

\section{SIMPULAN}

Bahasa sebagai simbol-simbol komunikasi agar dapat saling memahami. Kesantunan berbahasa tidak secara alami dimiliki seseorang, namun harus dilatih dan mendapat sentuhan dalam dunia pendidikan. Semakin baik pendidikan yang didapatkan oleh siswa, semakin berkualitas pula kemampuan berkomunikasinya. Nilai kesantunan berbahasa yang saat ini mulai mengalami penurunan dikalangan pelajar perlu di kokohkan kembali. Peran sentral orang tua dan guru dalam menginternalisasikan nilai kesantunan berbahasa melalui konsep pendidikan umum diharapkan menjadi salah satu kunci untuk memperbaiki tata bahasa yang ada dikalangan pelajar. Guru sebagai model dan teladan di sekolah harus mampu membangun maknamakna simbolik (symbolic) dan etika (ethics) saat proses belajar mengajar agar tercipta kualitas moral yang baik.

Seorang guru harus mampu berkomunikasi dengan siswa menggunakan bahasa yang santun agar terjadi interaksi sosial antar guru dan murid maupun sebaliknya, sehingga terwujudnya kesepakatan norma, etika dan moral yang dijunjung bersama dan di implementasikan dalam lingkup pendidikan. Dengan demikian sekolah dapat menjadi lembaga yang mampu mentransmisikan dan melestarikan nilainilai moral yang berkaitan dengan kesantunan berbahasa.

Tentunya membangun kesepakatan norma, etika dan moral berbahasa perlu di dukung oleh faktor eksternal lain seperti pentingya kesadaran dari orang tua yang berkaitan dengan penguatan nilai kesantunan berbahasa guna memberikan pemahaman dan konsistensi nilai bagi siswa sehingga nilai-nilai negatif bisa dihindari. Hilangnya intervensi dan kontrol dari orang tua akan memberikan celah bagi role model lain yang masuk melalui media teknologi sehingga dapat merusak kembali nilai-nilai yang ada dalam diri siswa yang telah didapatkan di sekolah.

\section{REKOMENDASI}

Beberapa saran yang direkomendasikan yang berkaitan dengan kesantunan berbahasa. 1) Bagi guru, harus secara konsisten dalam memberikan teladan dengan bahasa yang santun mengingat kondisi remaja saat ini banyak dipegaruhi oleh bahasa yang tidak santun. 2) Bagi orang tua, orang tua harus mampu mendukung dan memperkuat nilai kesantunan berbahasa yang sudah ditanamkan oleh guru disekolah. 3) Bagi peneliti selanjutnya, untuk dapat mengembangkan strategi internalisasi nilai kesantunan berbahasa ini secara lebih luas dan dengan jumlah populasi yang banyak agar hasil penelitian dapat di generalisasi secara lebih luas lagi. 
DAFTAR PUSTAKA

[1] Wa Ode Nurjamily, "Kesantunan Berbahasa Indonesia Dalam Lingkungan Keluarga (Kajian Sosiopragmatik)," J. Humanika, vol. 3, no. 15, pp. 64-65, 2017.

[2] F. Nur, D., \& Rokhman, "Kesantunan Berbahasa Mahasiswa dalam Berinteraksi di Lingkungan Universitas Tidar," J. Pendidik. Bhs. Dan Sastra Indones., vol. 6, no. 1, pp. 44-52, 2017.

[3] T. R. Budiawati, "Kesantunan Berbahasa Mahasiswa Dalam Berinteraksi Dengan Dosen Di UNIVERSITAS AHMAD DAHLAN," Urecol Proceeding, pp. 557-571, 2017.

[4] S. Sauri, "Pengembangan Strategi Pendidikan Berbahasa Santun di Sekolah," Mimb. Pendidik., vol. 22, no. 1, pp. 45-53, 2002.

[5] Sauri, "Pendidikan Karakter Dalam Perspektiif Islam," Rizki Press, p. 2019.

[6] S. B. Rasyid, "Fenomena Kedwibahasaan Di Sekolah Dasar; Sebuah Kondisi Dan Bentuk Kesantunan Berbahasa," J. Bid. Pendidik. Dasar, vol. 2, no. 2, pp. 62-72, 2018.

[7] Afriana dan Mandala, "Kesantunan Berbahasa Pada Pembelajaran Bahasa Inggris Maha Siswa Universitas Putera Batam," J. Basis, vol. 5, no. 2, 2018.

[8] Nasih dan Kholidah, Metode dan Teknik Pembelajaran Pendidikan Agama Islam. Bandung: Refika Aditama, 2013.

[9] S. Putri, K. C., Suwandi, S., \& Mulyono, "Ekspresi Kesantunan Berbahasa Dalam Pembelajaran Bahasa Indonesia Di Smp Muhammadiyah Gatak," J. Logat, vol. 7, no. 1, pp. 1-15, 2019.

[10] T. Lickona, Educating for
Character, How Our Schools Can Teach Respect and Responsibility. New York: Bantam Books, 2012.

[11] M. Muslich, Pendidikan karakter menjawab tantangan krisis multidimensional. Jakarta: PT. Bumi Aksara, 2010.

[12] Megawangi, Pendidikan karakter solusi yang tepat untuk membangun bangsa. Jakarta: Indonesia Heritage Foundation., 2016.

[13] I. Mustika, "Mentradisikan Kesantunan Berbahasa: Upaya Membentuk Generasi Bangsa yang Berkarakter.," J. Ilm. Progr. Stud. Pendidik. Bhs. Dan Sastra Indones., pp. 1-11, 2013.

[14] L. J. Moleong, Metodologi Penelitian Kualitatif. Bandung: PT Remaja Rosdakarya, 2010.

[15] J. Setyowati, H., \& Purwanto, "Pengembangan Model Pembelajaran Berbicara Bahasa Jawa Berbasis Analisis Kesantunan di Sekolah Menengah Kejuruan," J. Progr. Stud. Pendidik. Bhs. Dan Sastra Jawa_Universitas Muhammadiyah Purworejo, vol. 11, no. 1, pp. 158170, 2017.

[16] C. Geertz, Linguistic Eiquette Readings In The Sociology of Language. Paria: Mounton, 1972.

[17] H. Suryalaga, Etika Jeung Tatakrama. Bandung: Gegersunte, 1993.

[18] S. Arikunto, Prosedur Penelitian Suatu Pendekatan Praktik. Jakarta: Rineka Cipta, 2016.

[19] Kesuma, Pendidikan Karakter Kajian Teori dan Praktik di Sekolah. Bandung: PT. Remaja Rosdakarya, 2013.

[20] Y. Irwantoro, N, dan Suryana, Kompetensi Pedagogik. Sidoarjo: Genta group production, 2016. 
[21] N. Pramujiono, A., \& Nurjati, "Guru sebagai Model Kesantunan Berbahasa dalam Interaksi Instruksional di Sekolah Dasar," Mimb. Pendidik., vol. 2, no. 2, pp. 143-154, 2017.

[22] Hakam, "Internalisasi Pendidikan Karakter di Sekolah Dasar," in Disampaikan dalam Seminar Nasional di Universitas Indonesia tahun 2015, Disajikan di Balai Besar Pelatihan Kesehatan Jakarta 2016, dan Seminar Nasional di Institut Hindu Dharma Negeri (IHDN) Denpasar tahun 2016, 2016.

[23] I. S. Sakti, T. K., Hairunisya, N., \& Sujai, "Pengaruh Kompetensi Pedagogik Guru dan Gaya Belajar Siswa Terhadap Prestasi Belajar Siswa Pada Mata Pelajaran IPS," URNAL Pendidik. ILMU Sos., vol. 28, no. 1, pp. 53-60, 2019.
[24] A. Rehalat, "Model Pembelajaran Pemrosesan Informasi," J. Pendidik. Ilmu Sos., vol. 23, no. 2, pp. 1-10, 2014.

[25] A. F. Zakaria, "No TitleSTUDI TENTANG UPAYA GURU IPS DALAM MENGEMBANGKAN PERILAKU PROSOSIAL DAN MENGURANGI PERILAKU BULLYING SISWA DI SMP (Studi Kasus pada Guru IPS SMP PGRI 1 Jatinangor Kab. Sumedang Jawa Barat).," J. Pendidik. Ilmu Sos., vol. 25, no. 1, pp. 117-123, 2016.

[26] P. Dianti, "Integrasi Pendidikan Karakter dalam pembelajaran Pendidikan Kewarganegaraan untuk mengembangkan karakter siswa," J. Pendidik. Ilmu Sos., vol. 23, no. 1, 2014. 